\title{
Manfaat Pemisahan Sampah Organik dan Anorganik Melalui Media Buku Ilustrasi Anak
}

\author{
Ardani Ari Suseno ${ }^{1)}$, Nabila Ulul Albab ${ }^{2)}$, Sonde Martadireja ${ }^{3)}$ \\ 1), 2), 3) Desain Komunikasi Visual Politeknik PalComTech \\ Jl. Basuki Rahmat No.05, Palembang 30129, Indonesia \\ e-mail: ardanisuseno99@gmail.com ${ }^{1)}$,nabilahululalbab@gmail.com ${ }^{2)}$, \\ sonde.martadireja@gmail.com ${ }^{3)}$,
}

\begin{abstract}
Garbage was defined as the residue of people's daily activities. In the social environment, to facilitate decomposition, garbage was generally grouped into two simple parts; namely organic garbage and inorganic garbage. garbage management was needed to reduce the possibility of positive and negative impacts to the environment. Economic value was grouped into positive impact, while the source of odors and disease clusters were grouped as negative impact. In this study, the focus of the problem is on the negative group. Because if garbage is allowed to pile up in one place in community settlements, it will become a source of unpleasant odors so that it can then become an area for germs to develop. This condition is an indication that the garbage had not been managed properly and could worsen the surrounding environment. Therefore, proceeded from the scientific visual communication design, then at least hazard information and proper garbage processing method needed to be made. Knowledge of garbage separation to reduce environmental pollution would be better if known or understood since childhood. The choice of work form for dissemination of this information was children illustration book. The process of realizing this illustration book work used several stages, the first stage was the process of collecting data about garbage and its processing, then data on the type of book that match the target audience. The second stage was the process of making books, in this stage it went through several processes from pre-production to production.
\end{abstract}

Keywords: Illustration, Children, Health, Garbage

\begin{abstract}
ABSTRAK
Sampah diartikan sebagai sisa kegiatan sehari-hari manusia. Di lingkungan sosial masyarakat, untuk mempermudah penguraian, umunya sampah dikelompokkan menjadi dua bagian sederana; yaitu sampah organik dan sampah anorganik. dibutuhkan pengelolaan sampah yang untuk mengurangi kemungkinan dampak positif dam negatif ke lingkungan. Nilai ekonomis dikelompokkan dalam dampak positif, sedangkan, sumber bau dan kluster penyakit masuk dalam kelompok negatif. Pada penelitian ini, fokus masalah ada pada kelompok negatif. Karena apabila sampah dibiarkan menumpuk disatu tempat di pemukiman masyarakat, akan menjadi sumber bau yang tidak sedap sehingga kemudian dapat menjadi wilayah berkembangnya bibit penyakit. Kondisi ini menjadi indikasi bahwa sampah belum dikelola dengan baik dan dapat memperburuk kondisi lingkungan disekitarnya. Oleh karena itu, berangkat dari keilmuan desain komunikasi visual, maka paling tidak informasi bahaya dan cara pengolahan sampah yang tepat perlu dibuat. Pengetahuan tentang pemisahan sampah untuk mengurangi timbulnya pencemaran lingkungan, akan lebih baik jika diketahui atau dipahami sejak anak-anak. Pilihan bentuk karya untuk penyebaran informasi ini adalah buku ilustrasi anak. Proses mewujudkan karya buku ilustrasi ini menggunakan beberapa tahapan, tahap pertama yaitu proses pengumpulan data mengenai sampah dan proses pengolahannya, kemudian data mengenai jenis buku yang sesuai dengan target pembaca. Tahap kedua yaitu proses pembuatan buku, dalam tahap ini melewati beberapa proses dari pra produksi sampai produksi.
\end{abstract}

Kata Kunci :Ilustrasi, Anak, Kesehatan, Sampah 


\section{Pendahuluan}

Pertumbuhan jumlah penduduk yang sangat pesat memberikan dampak terhadap lingkungan dalam kehidupan masyarakat. Salah satu dampak yang dihasilkan dari pertumbuhan jumlah penduduk adalah meningkatnya jumlah sampah yang dihasilkan dari aktivitas masyarakat sehari-hari. Dalam Undang-Undang Nomor 18 Tahun 2008 tentang Pengelolaan Sampah, sampah adalah sisa kegiatan sehari-hari manusia atau proses alam yang berbentuk padat. Sampah merupakan bagian yang tidak dapat dipisahkan dari kehidupan manusia, karena pada dasarnya semua manusia pasti menghasilkan sampah.

Pada umumnya sampah yang dihasilkan oleh masyarakat meliputi sampah organik dan sampah anorganik. Sampah organik adalah sampah yang berasal dari bahan-bahan hayati. Jenis sampah ini bersifat dapat dengan mudah didegradasi atau diuraikan dalam proses alami, baik secara aerob maupun anaerob. Penguraian itu dilakukan oleh mikroba pengurai yang terdapat di alam. Oleh karena itu, sampah organik bersifat biodegradable (Nugroho, 2019). Contoh sampah organik seperti sisa makanan, sayur-sayuran, buah-buahan, daun kering dan sebagainya. Sampah ini bisa dikatakan sebagai sampah ramah lingkungan. Bahkan sampah ini dapat diolah lebih lanjut menjadi pupuk tanaman. Tetapi apabila sampah tidak dikelola dengan benar akan memicu timbulnya penyakit, selain itu juga akan timbul bau yang kurang sedap akibat dari hasil pembusukan sampah organik yang cepat.

Sampah anorganik adalah sampah yang berasal dari bahan-bahan nonhayati. Bahan non hayati dapat berupa produk sintetik, hasil olahan teknologi bahan tambang, hasil olahan bahan hayati, dan sebagainya. Bahan-bahan tersebut umumnya sulit diuraikan dalam proses alami. Contohnya seperti kantong plastik, botol minuman, sisa kain, ban bekas, dan lainnya. Sampah anorganik juga bisa menjadi sesuatu yang bermanfaat bila dikelola dengan tepat. Tetapi apabila sampah anorganik ini tidak dikelola dengan tepat dapat mengakibatkan penceraman lingkungan, karena sampah anorganik tergolong zat yang sulit terurai.

Saat sampah organik dan anorgnik tercampur, maka dapat menyebabkan sulit terurainya sampah organik dan hilangnya nilai ekonomis dari sampah anorganik itu sendiri. Apabila keadaan tersebut berlangsung terus menerus maka akan mengakibatkan sampah menumpuk di tempat penampungan sampah. Selain itu juga apabila tidak dikelola dengan baik, maka dapat memperburuk kondisi lingkungan di sekitarnya. Yaitu, menjadi sumber bau yang tidak sedap sehingga kemudian dapat menjadi bibit penyakit.

Berdasarkan narasi kondisi di atas, maka dibutuhkan pengelolaan sampah yang baik untuk mengurangi dampak buruk ke lingkungan. Oleh karena itu, diperlukan pengetahuan tentang pemisahan sampah untuk mengurangi timbulnya pencemaran lingkungan, dan akan lebih baik jika pengetahuan terserbut diketahui atau di pahami sejak anak-anak.
Berdasarkan keilmuan dan keahlian penulis, untuk media yang digunakan dalam mengedukasi anak tentang pentingnya memisahkan sampah organik dan anorganik ini, penulis memilih menggunakan media buku cerita dengan ilustrasi penuh bergaya gambar dan cerita yang mudah dipahami oleh anak. Ilustrasi sendiri, menurut definisinya adalah seni gambar yang dimanfaatkan untuk memberi penjelasan atas suatu maksud atau tujuan secara visual (Kusrianto, 2009).

Jadi, tujuan dari penelitian ini adalah untuk mengedukasi anak tentang pentingnya memisahkan sampah organik dan anorganik dengan menggunakan media buku ilustrasi. Manfaat bagi penulis yaitu dapat meningkatkan wawasan pengetahuan tentang manfaat pemisahan sampah organik dan anorganik, selain itu penulis juga dapat menerapkan ilmu yang diperoleh selama perkuliahan. Kemudian manfaat bagi target audience (anak-anak) yaitu mendapatkan pembelajaran mengenai manfaat pemisahan sampah organik dan anorganik.

Metode yang digunakan dalam penelitian ini menggunakan pendekatan analisis kualitatif. Menurut (Suharsaputra, 2018) metode penelitian kualitatif adalah prosedur penelitian yang menghasilkan data deskriptif berupa kata-kata tertulis atau lisan dari orang-orang dan perilaku yang dapat diamati. Caranya adalah mewawancarai objek penelitian di tempat pengolahan sampah. Dalam proses pengumpulan data penulis menggunakan objek penelitian (tempat) berupa TPS (Tempat Pengolahan Sampah) Kalidoni karena di tempat tersebut penulis bisa mendapatkan data mengenai cara dan manfaat pengolahan sampah organik dan anorganik. Selain itu penulis juga melibatkan anak-anak sebagai objek penelitian (target audience) dikarenakan anakanak lebih mudah diberikan materi dasar untuk pondasi mereka. Kemudian dengan menjadikan anak-anak sebagai target audience merupakan salah satu upaya untuk mengurangi intensitas pemakaian gawai pada anak-anak. Lalu berdasarkan data yang didapat dilapangan tersebut, kemudian penulis menjadikannya pedoman dasar untuk diolah menjadi bentuk karya desain komunikasi visual (sesuai hasil pilihan penulis) yaitu buku ilustrasi dengan gaya gambar dan bercerita untuk anak-anak.

\section{Pembahasan}

Setelah melewati proses pengumpulan data, selanjutnya penulis mulai masuk ke tahap pembuatan buku ilustrasi yang diawali dengan proses pra produksi sampai produksi.

\section{Praproduksi}

Tahap praproduksi meliputi beberapa proses yaitu penentuan alur cerita buku, kemudian pembuatan konsep cerita yang menjadi landasan utama dalam pembuatan buku ilustrasi anak ini. Setelah menentukan konsep cerita, kemudian dilanjutkan dengan menerjemahkan 
kalimat dikonsep cerita menjadi gambaran sketsa dasar dalam bentuk storyboard.

Konsep atau naskah cerita buku ini adalah:

1. Sepulang sekolah aku sedang berjalan kaki. Lalu, aku menemukan tumpukan sampah yang tidak sedap. "Duhhh.. bau sampahhh"

2. Hampir sampai dirumah, ada orang yang sedang membakar sampah, "Aduhh asapnyaa.. bikin dadaku sesak, mataku juga perih". Akupun terbatuk dan langsung menutup hidung.

3. Sesampai dirumah, aku cerita ke Ibu "Bunda, tadi Azmi nyium bau busuk samapah disana. Terus ketemu orang bakar sampah asapnya bikin batuk dan mataku perih. Lalu Bunda menjawab "Waduh itu gak baik sebenarnya. Yaudah, masuk dulu ganti baju terus makan".

4. Setelah masuk kedalam rumah, aku dan bunda siap-siap untuk makan siang. Lalu bunda mengajakkua ke tempat pengolahan sampah untuk melihat langsung proses pengolahan sampah. " nah, besok kan hari libur. Nanti Bunda ajak Azmi ke tempat pengolahan sampah".

5. Keesok harinya bunda memanggilku "Azmi, sudah siap belum. Ayo kita pergi ketempat pengolahan sampah sekarang".

6. Aku dating dan menggampiri ibu. "lho kok bawa sampah Bun?. Ibu menjawab" iya nanti bunda jelasin disana".

7. Azmi dan Ibu pergi ke tempat pengolahan sampah sambil membawa sampah.

8. Sesampai ditempat pembuangan sampah, Azmi berkata "Ohh ini ya bun tempat pengolahan sampahnya". "Iya, disinalah tempat pengolahan sampah yang didaur ulang kembali".

9. Bunda dan Azmi melihat proses pengolahan sampah organik. "Nah, kayak gini proses pengolahan sampah organik".

10. Bunda dan Azmi melihat proses pengolahan sampah anorganik. "Nah, kayak gini proses pengolahan sampah anorganik".

11. Setelah itu Bunda menyampaikan pesan-pesan. “ dengan melakukan pengolahan sampah yang benar, berarti kita sudah berupaya untuk menjaga kelestarian lingkungan yang kita cintai ini. Yuk budayakan buang sampah sesuai tempatnya"

12. Permainan.

\section{Produksi}

Pada tahap produksi penulis membuat sketsa berdasarkan storyboard yang telah dibuat sebelumnya. Dalam pembuatan sketsa yang dilakukan dengan cara digital menggunakan perangkat lunak Adobe Photoshop CC 2019.

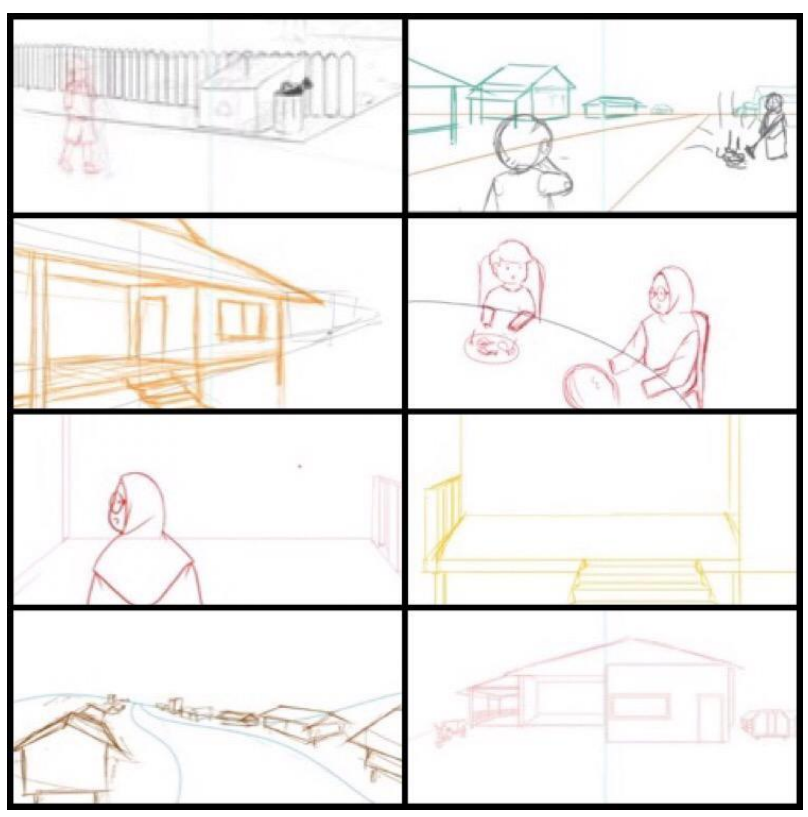

Gambar 1. Sketsa

Setalah sketsa dibuat maka dilanjutkan dengan tahap pewarnaan. Dalam proses pewarnaan ini penulis melewati beberapa tahapan, pertama mewarnai dengan warna dasar (solid) kemudian setelah itu dilanjutkan dengan memberikan warna gelap terang.

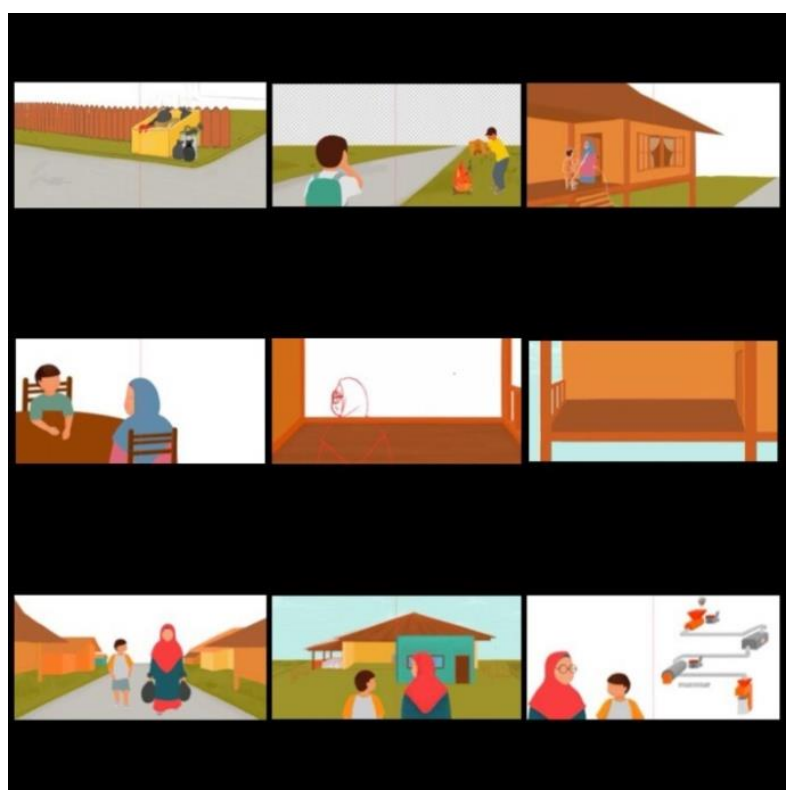

Gambar 2. Pewarnaan buku.

Pembuatan buku ilustrasi ini menggunakan beberapa landasan konsep, yaitu layout, huruf, dan warna. Penjelasnnya adalah: Pertama, pada layout penulis menerapkan satu gambar llustrasi untuk dua halaman yang berdampingan. Konsep seperti ini diharapkan dapat memberikan ruang yang lebih luas bagi pembaca untuk menikmati buku ilustrasi tersebut nantinya.

Kedua, huruf pada buku ilustrasi ini menggunakan tiga jenis huruf sans serif atau "tanpa kaki" untuk 
memberikan kesan dinamis dan ceria yang sesuai dengan karakter anak-anak. Ketiga jenis huruf tersebut adalah bakso sapi, future, dan candy beans.

Huruf bakso sapi digunakan sebagai judul buku dikarenakan jenis huruf ini memiliki karakter dan ciri khas yang kuat. Jenis huruf futura digunakan sebagai narasi dalam buku dikarenakan jenis huruf ini memiliki tingkat keterbacaan yang tinggi sehingga memudahkan pembaca dalam membaca cerita pada buku tersebut. Lalu, jenis huruf candy beans digunakan sebagai dialog karakter ibu dan anak dalam buku.

\begin{tabular}{|c|c|c|}
\hline $\begin{array}{l}\text { BAKSO SAPi } \\
\text { UPPERCASE LETTER } \\
\end{array}$ & 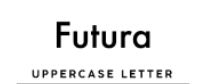 & $\begin{array}{l}\text { Candy Beans } \\
\text { UPpercase LetTER }\end{array}$ \\
\hline $\begin{array}{l}\text { ABCDEFGH } \\
\text { i JKLMNOPQ }\end{array}$ & $\begin{array}{l}\text { ABCDEFGH } \\
\text { IJKLMNOPQ }\end{array}$ & $\begin{array}{l}A B C D E F G H \\
\text { IJKLMNOPQ }\end{array}$ \\
\hline $\begin{array}{c}\boldsymbol{R} \boldsymbol{S} \mathbf{T} \boldsymbol{U} \boldsymbol{V} \mathbf{W} \mathbf{X} \boldsymbol{Y} \mathbf{Z} \\
\text { NUMBer }\end{array}$ & RSTU U WWXYZ & $\begin{array}{c}\text { RST } \\
\text { NUMBER } \\
\end{array}$ \\
\hline 1234567890 & 1234567890 & 1234567890 \\
\hline 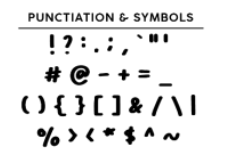 & 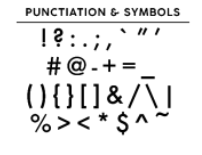 & 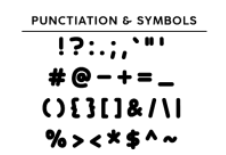 \\
\hline
\end{tabular}

Gambar 3. Huruffuture, Bakso sapi, dan Candy beans.

Ketiga, warna yang akan digunakan dalam buku ini menggunakan kombinasi warna analogus dan komplementer. Warna analogus itu sendiri adalah warnawarna yang berdekatan dalam roda warna, sedangkan warna komplementer adalah warna yang letaknya berlawanan dalam roda warna.

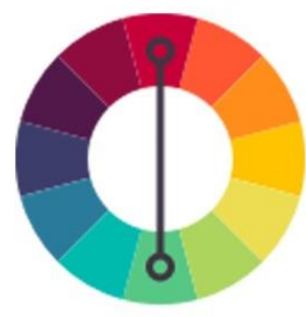

Complementary

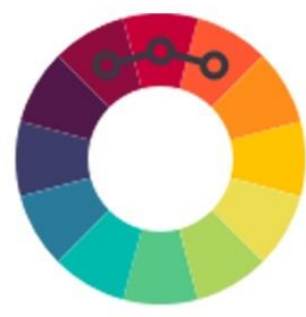

Analogous
Gambar 4. Visualisai aturan warna complementer dan analogus.

(Sumber (CartoCSS, 2019))

\section{Hasil Buku}

Hasil akhir dari proyek tugas akhir ini adalah buku ilustrasi anak dengan judul "Aku Bisa Memilah Sampah". Buku ilustrasi ini diharapkan dapat membantu anak-anak dalam memahami mengenai manfaat pemisahan sampah organik dan anorganik.

Buku ini diawali dengan cerita tentang seorang anak yang baru pulang sekolah. Kemudian di tengah perjalanan dia terganggu dengan aroma tumpukan sampah dan asap hasil pembakaran sampah. Si anak pun melaporkan kejadian itu kepada ibunya. Keesokan harinya ibunya mengajak anak untuk melihat proses pengolahan sampah di Tempat Pengolahan Sampah (TPS).

Sampul depan buku ilustrasi ini dirancang dengan suasana alam yang bersih dan nyaman terutama bagi anak, dalam sampul depan penulis mengilustrasikan seorang anak dengan ekspresi bahagia karena sudah bisa membuang dan memilah sampah sebagaimana mestinya.

Sebagai identitas buku, penulis memilih huruf bakso sapi pada judul yang memiliki penekanan dibanding objek lain dengan cara meletakkannya di posisi atas dengan ukuran yang cukup besar. Kemudian dari segi warna huruf, penulis menggunakan warna yang sama dengan batang pohon untuk memberikan kesatuan pada desain sampul depan tersebut. Selanjutnya sampul depan ini dicetak dengan ukuran 20x20 cm dan menggunakan bahan hard cover greyboard ukuran $3 \mathrm{~mm}$.

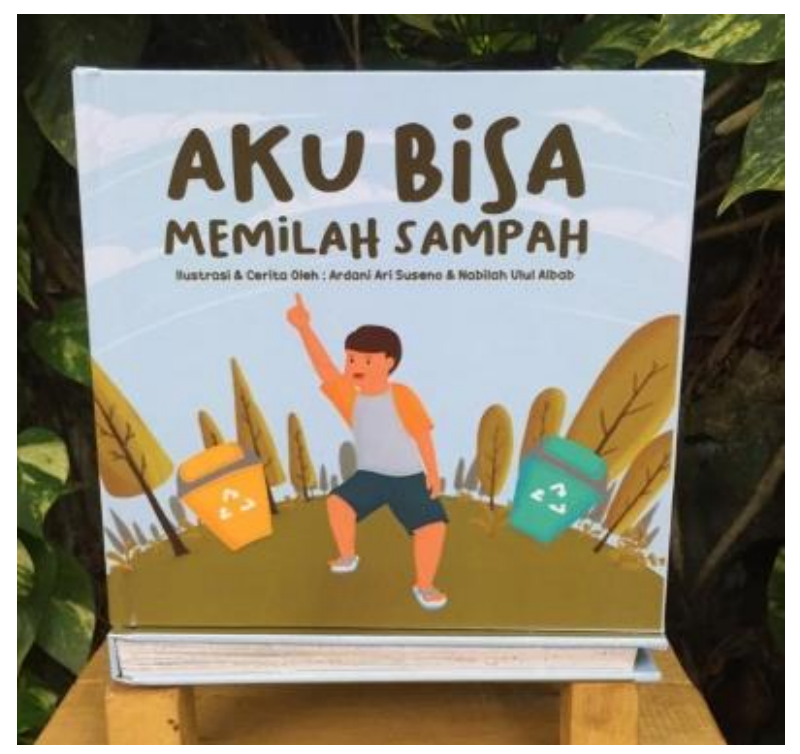

Gambar 5. Sampul depan buku.

Bagian isi buku ini diawali dengan pengenalan tokoh yang ada terlebih dahulu. Ulul Azmi sebagai anak dan Hanifah adalah ibu.
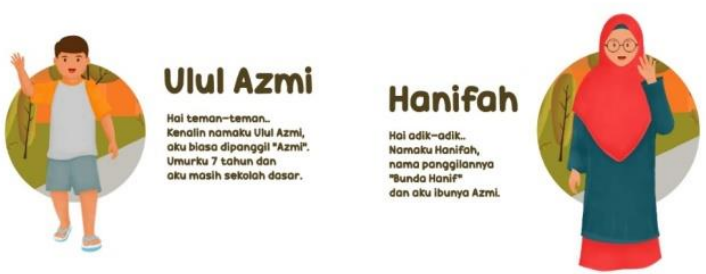

Gambar 6. Pengenalan tokoh dalam buku.

Cerita dimulai dari karakter Ulul Azmi yang berjalan pulang dari sekolah, kemudian di tengah perjalanan dia mencium aroma tidak sedap dari tumpukan sampah. Dalam ilustrasi ini penulis menggunakan warna yang kontras antara objek utama (karakter anak dan tumpukan sampah) dengan warna latar belakang yang menggunakan warna analogus. 


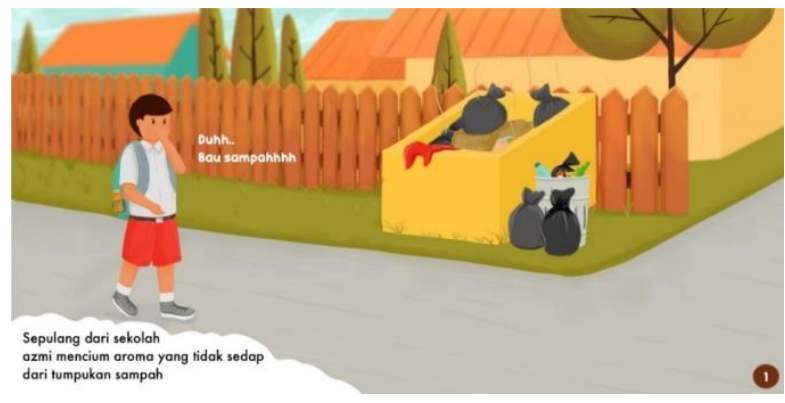

Gambar 7. Ulul Azmi mencium aroma sampah.

Lalu penggambaran Ulul Azmi sedang mengadu pada ibunya tentang aroma sampah yang mengganggu dirinya dengan menunjuk ke arah jalan yang sebelumnya dilaluinya. Dalam ilustrasi ini penulis menggunakan jenis layout rata kiri, lalu penulis meletakkan close up karakter ibu di pojok kanan atas untuk mengisi ruang kosong di area tersebut dan juga sebagai tempat untuk menulis dialog. Warna objek utama dibuat berlawanan dengan latar belakang yang memungkinkan karakter tetap menjadi jadi titik pusat perhatian walaupun dengan ukuran yang tidak terlalu besar.

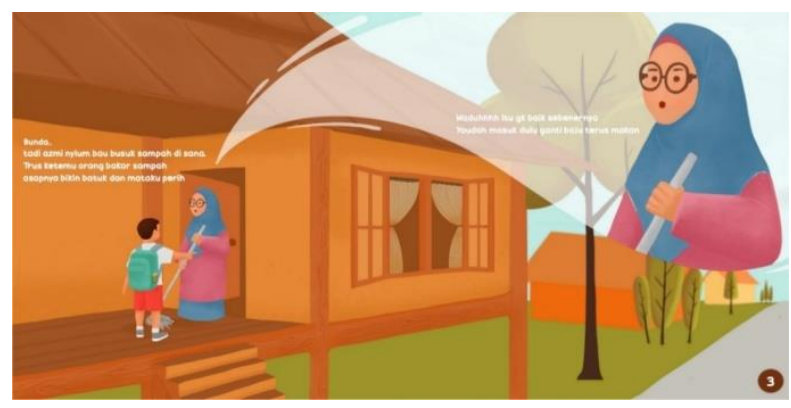

Gambar 8. Ulul Azmi mengadu pada Ibunya.

Hanifah (Ibu) mengajak Ulul Azmi ke Tempat Pembuangan Sampah untuk memberi pengetahuan tentang sampah secara langsung. Layout yang digunakan dalam ilustrasi ini adalah rata tengah untuk memberikan keseimbangan dalam ilustrasi ini. Penulis juga meletakkan objek yang kontras dengan latar belakang seperti kedua karakter, bangunan dan peralatan pengolah sampah di tengah-tengah untuk memberikan kesatuan pada objek penting.

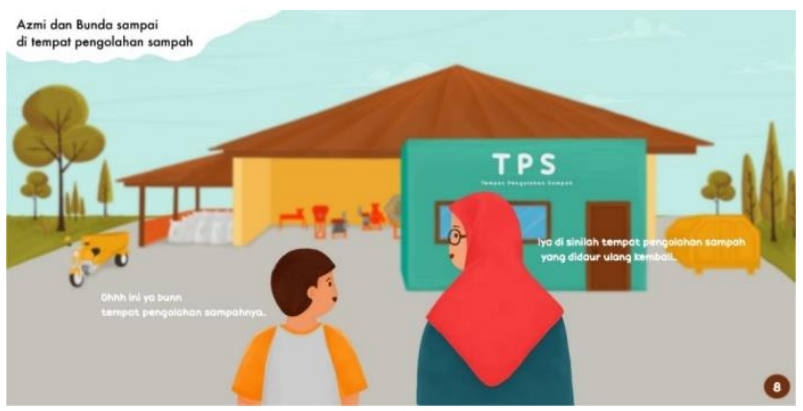

Gambar 9. Hanifah (Ibu) mengajak Ulul Azmi ke TPS.
Penjelasan tentang proses pengolahan sampah pada ilustrasi ini menggunakan bentuk infografis untuk memudahkan pembaca dalam memahami isi materi yang disampaikan. Objek TPS sebagai latar belakang diblur untuk membuat pembaca dapat lebih fokus membaca infografis

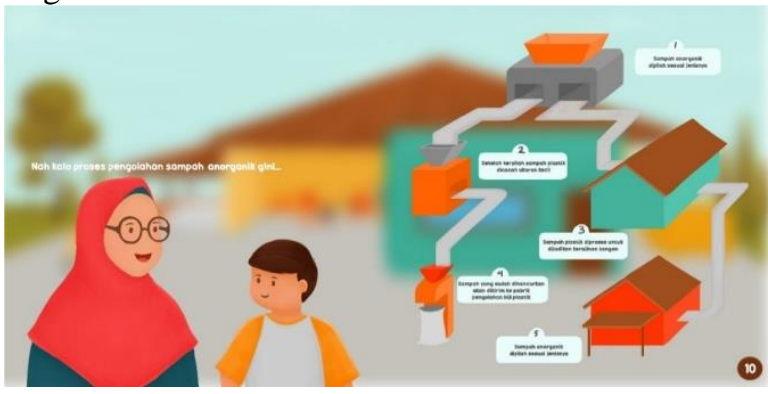

Gambar 10. Penjelasan pengolahan sampah

Pada akhir cerita, karakter hanifah (Ibu) memberikan pesan dan nasehat untuk pembaca tentang pengolahan sampah yang benar.. Pada halaman ini penulis menggunakan warna hitam pada tulisan supaya kontras dan dapat memudahkan dalam membaca.

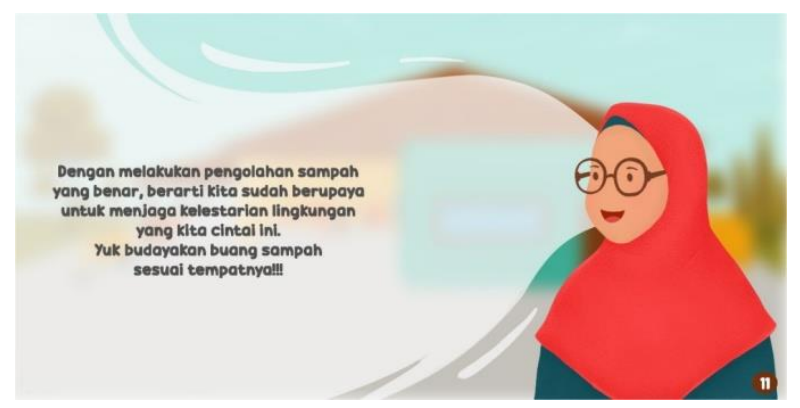

Gambar 11. Pesan dan nasehat (kesimpulan).

Pada akhir isi buku, terdapat tambahan yaitu permainan interaktif yang diharapkan dapat menghilangkan rasa bosan saat membaca buku, dan juga dapat membuat anak-anak dapat berinteraksi langsung dengan materi yang disampaikan dalam buku. Permainannya adalah memasukkan sampah sesuai tempatnya dan labirin sampah.

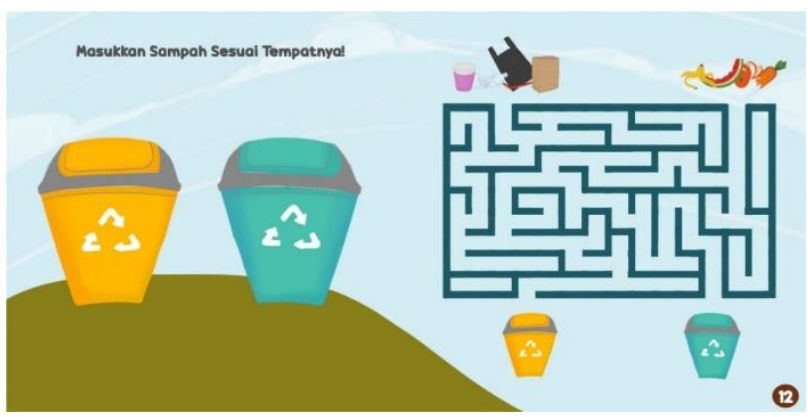

Gambar 12. Sisipan permainan interaktif. 
Lalu, sampul belakang buku ilustrasi "Aku Bisa Memilah Sampah" ini menggunakan konsep yang sama dengan sampul depan, namun hanya menampilkan gambar pemandangan kosong tanpa objek karakter dan kotak sampah lalu menambahkan paragraf tentang penjelasam singkat isi buku ini. Aturan desain tata letak yang digunakan dalam desain ini adalah rata tengah, kemudian meletakkan tulisan di tengah dengan warna hitam dengan latar belakang biru langit yang membuatnya menjadikannya sebagai pusat perhatian dalam desain sampul belakang tersebut.

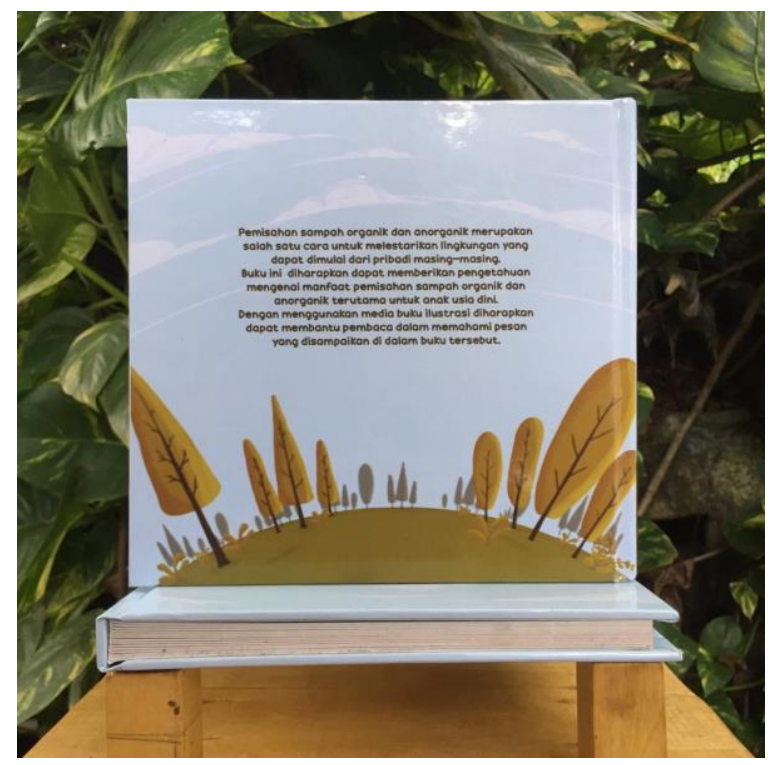

Gambar 13. Sampul belakang buku.

\section{Kesimpulan}

Permasalahan sampah yang menumpuk salah satunya diakibatkan oleh pengolahan sampah yang kurang maksimal. Hal ini dapat diatasi dengan cara memisahkan sampah sesuai jenisnya supaya sampah tersebut dapat diolah menjadi sesuatu yang berguna seperti pupuk kompos, bahan biji plastik, dan kerajinan tangan yang dapat mengurangi volume sampah di sekitar masyarakat. Mengenai permasalahan di atas, diperlukan edukasi tentang pemisahan sampah, dalam hal ini anak-anak menjadi target sasaran (audience) untuk mendapat edukasi masalah tersebut dikarenakan anak-anak memiliki rasa ingin tahu yang tinggi. Dengan menggunakan buku ilustrasi diharapkan dapat membuat anak-anak memahami masalah pemisahan sampah organik dan anorganik sejak dini.

\section{DaftarPustaka}

Kusrianto, A. (2009). Pengantar Desain Komunikasi Visual. CV Andi Offset.

Nugroho, F. (2019). Berkah Mengolah Sampah (A. Firmayani (ed.)). CV Sindunata.

Republik Indonesia. (2008). Undang-undang No.18 Tahun 2008 tentang Pengolahan Sampah.
Suharsaputra, U. (2018). Metode Penelitian Kuantitatif, Kualitatif, dan Tindakan. PT Refika Aditama.

\section{Laman}

CartoCSS. (2019). CartoCSS Color Mixing Functions. https://carto.com/help/tutorials/cartocss-colormixing-functions/ 